\title{
State of art of hydrogen usage as a fuel on aviation
}

\section{Meryem Gizem Sürer ${ }^{1}$, Hüseyin Turan Arat ${ }^{2, *}$}

\author{
'Dept. of Mechanical Engineering, İskenderun Technical University, Hatay/TURKEY \\ 2 Dept. of Mechatronics Engineering, İskenderun Technical University, Hatay/TURKEY
}

\begin{abstract}
Air transportation phenomenon is placed with sharing of world energy consumption between $2.5 \%$ and $5 \%$ totally and showing an increasing perspective approximately $4.8 \%$ per year. With the increasing world population and the energy consumption, the aviation industry has led the technology and researches to alternative and/or renewable energy sources depending on the risk of depletion on kerosene fuels and its effects on the price increasement and environmental negativeness. Hydrogen energy, which $\mathrm{H} 2$ is the most abundant element in the universe and most of it exists in the form of water and organic compounds, is considered the most promising fuel for all vehicles which need to effective energy. The diversity of availability and the renewability of hydrogen fuel have opened the way for use in different engineering applications with the creation of an environmentally friendly. The aerospace and aviation sectors have been the earlier to recognize the importance of using this fuel. The union of aviation industry and hydrogen energy has been met with NASA's works and has become remarkable position with the developing technology. This paper aim is touched upon the system of hydrogen usage strategies in aviation as a fuel. For this purpose, the brief history of using $\mathrm{H} 2$ in aviation were presented, then benefits and challenges were given with explanatory, engineering technology of usage $\mathrm{H} 2$ were analyzed, fuel cell applications and liquid forms of $\mathrm{H} 2$ is explained as a focus of fuel and storage necessity were discussed, new technologies approachment were analyzed and given with comparisons. As a result, a mini but detailed review perspective on state of art on usage hydrogen energy in aviation would be emphasized.
\end{abstract}

Keywords: Hydrogen, Hydrogen Production and Storage, Fuel Cell, Green Aviation.

\section{INTRODUCTION}

Air transport industry, which has the effect of accelerating the economic and social advancement of the country, is becoming increasingly part of our lives [1]. This type of transportation is increasing its freedom and preference with developing technology. Despite complex engineering features and calculations, it is rapidly evolving in intensive work on the industry. Over the last 20 years, air transport has increased by $4.8 \%$ each year its capacity, which affected the number of jet aircrafts [2]. Additionally, the Boeing Current Market Outlook estimated that the numbers of jets were 19.000 by 2008 would rise to 35.800 in 2027 [3].

Aircraft carries too much load so that there is a very wide range of weights with a maximum take-off weight of up to 640 tons. To carry these loads, large and powerful engines needed and these engines use a lot of fuel requirement. This fuel requirement comes up with its benefits and challenges with the properties of fuel safety, fuel cost, specific energy, and equivalent energy efficiency. Today, aircrafts mostly use petroleum-based fuels obtained from fossil fuels. Among these fuels, flight cost of the most preferred kerosene is less than other fuels $[4,5]$. The average chemical composition of kerosene by percent is: 35 percent alkenes (paraffins), 60 percent cyclic alkanes (naphthenes), 15 percent aromatics. Flash point and auto-ignition temperature are $38-74^{\circ} \mathrm{C}$ and $229^{\circ} \mathrm{C}$, respectively [6].

Although kerosene and some blends of gasoline were preferable usage potential as a fuel for aviation; their reserves are doomed to death and increased green house emission parameters affect the environment negatively. With these considerations, researchers and manufacturers find new ways and forms of energy handling with alternative/renewable energetic fuels.

When it comes to selection the right fuel; Dinçer and Biçer [5] donated the fundamental requirements of air vehicle fuels. [5] listed the properties of air vehicle fuels as;

$\checkmark \quad$ "High levels of maximum range or payload heat. This indicates a high specific energy and high energy density.

${ }^{*}$ Corresponding authour

Email: hturan.arat@iste.edu.tr (H. T. Arat) 
$\checkmark$ Good atomization, rapid evaporation, good burning properties, including the ability to lower high and low risk of explosion.

$\checkmark \quad$ High specific heat capacity, pollution-free, low carbon formation.

$\checkmark \quad$ Low viscosity and high lubricity, good characteristics of pumped storage, including low freezing point, in order to facilitate the operation amount.

$\checkmark \quad$ High stability thermal/chemical stability, wide availability and price acceptable and respects the environment.

$\checkmark$ Proper ground and handling characteristics" [5].

In addition to all these, all large and small air vehicles should be environmentally friendly. The aviation sector is responsible for $12 \%$ of $\mathrm{CO}_{2}$ emissions from all transports vehicle and around $80 \%$ of aviation $\mathrm{CO}_{2}$ emissions are stem from flights of over $1500 \mathrm{~km}$ [7]. Only in 2015, through all around the world flights generated 770 million tons of CO 2 [5]. Koroneos et al. [8] referred to the negative environmental effects of kerosene, which are mainly $\mathrm{CO}_{2}$ and $\mathrm{SO}_{2}$ emissions. They determined that the greatest environmental destruction of kerosene is the $\mathrm{SO}_{2}$ emission, which plays an important role in the formation of acid rain.

With these considerations and re-positioning of this worst advantage scale, conventional fossil fuels using in aviation have begun to give a chance to new engine technologies and alternative fuels. One of the most important elements of the fuel family is hydrogen. Hydrogen has become the focus of attention for researchers and combustion experts during last years because of availability, better specific energy properties and environmental benefits.

Dinçer and Acar [4] stated that hydrogen has two types of use as fuel in airplanes. The first way is to use hydrogen as a fuel instead of kerosene in big airplanes and the second way is to use of hydrogen fuel cells, especially polymer membrane fuel cells, instead of jet engines in small propeller airplanes. Sharpe et al. [9] studied the hydrogen utilization in supersonic/hypersonic aircrafts as an alternative aircraft fuel. They mentioned that hydrogen, which is produced sustainably and has the highest energy per unit mass compared to any chemical fuel, is an excellent energy store. However, the volumetric density of hydrogen with a very low energy density per unit volume should be increased for use in aviation. Compatibility and infrastructural items of hydrogen would need to improve further. Verstraete [10] compared hydrogen and kerosene fuelled long-range aircraft in today's and tomorrow's aviation technology. They also reported that when hydrogen is used instead of petroleum-based fuels in airplanes, the percentage of water vapor that increases the specific heat of combustion gases increases. This situation causes a lower pressure drop in the turbine, producing more thrust.

Table 1 The properties of hydrogen [data gathered from 4,5,13]

\begin{tabular}{|l|l|}
\hline \multicolumn{1}{|c|}{ Hydrogen Property } & \\
\hline Octane number & $130+$ \\
\hline Auto ignition temperature & $585^{\circ} \mathrm{C}$ \\
\hline Lower heating value (at $25^{\circ} \mathrm{C}$ and $\left.1 \mathrm{~atm}\right)$ & $119.93 \mathrm{~kJ} / \mathrm{g}$ \\
\hline Higher heating Value $\left(\right.$ at $25^{\circ} \mathrm{C}$ and $\left.1 \mathrm{~atm}\right)$ & $141.86 \mathrm{~kJ} / \mathrm{g}$ \\
\hline Boiling point & $-252.7^{\circ} \mathrm{C}$ \\
\hline Melting point & $-259.2^{\circ} \mathrm{C}$ \\
\hline Density of boiling point & $70.8 \mathrm{~kg} / \mathrm{m}^{3}$ \\
\hline Vapor density (at $\left.68^{\circ} \mathrm{F} ; 20^{\circ} \mathrm{C}, 1 \mathrm{~atm}\right)$ & $0.08376 \mathrm{~kg} / \mathrm{m}^{3}$ \\
\hline Specific volume at liquid form $-253^{\circ} \mathrm{C}$ and $1 \mathrm{~atm}$ & $0.014 \mathrm{~m}^{3} / \mathrm{kg}$ \\
\hline Specific volume at gas form at $20^{\circ} \mathrm{C}$ and $1 \mathrm{~atm}$ & $11.9 \mathrm{~m}^{3} / \mathrm{kg}$ \\
\hline Flash point & $<-253{ }^{\circ} \mathrm{C} ; 20 \mathrm{~K}$ \\
\hline Flame temperature & $2,1588^{\circ} \mathrm{C}$ \\
\hline Air/fuel mass & 34.2 \\
\hline Energy consumption & $316,5 \mathrm{Mj} / \mathrm{km}$ \\
\hline Fuel consumption & $2.64 \mathrm{~kg} / \mathrm{km}$ \\
\hline Heat of combustion & $120 \mathrm{~kJ} / \mathrm{kg}$ \\
\hline Heat of vaporisation & $446 \mathrm{~kJ} / \mathrm{kg}$ \\
\hline
\end{tabular}

This technology must be further developed because it has significant disadvantages as well as advantages of using hydrogen as a fuel in airplanes. Hydrogen, with all the properties required for its use as fuel, has the highest energy content per unit mass of all known fuels (2.8 times higher than compared to kerosene) [5,11]. This property very important because it allows for a greater payload[12]. Another advantage is that hydrogen promises that long-term growth in aviation by protecting the environment [11]. Hydrogen produces only water vapor and a small amount of $\mathrm{NO}_{\mathrm{x}}$ as the combustion product [11-12]. Koroneos and Moussiopoulos [11], Contreras et al.[12] studied the environmental effects of using hydrogen as a fuel and concluded that hydrogen is the one of most promising options for the environment because it 
does not contain emission that adversely affect the environment such as $\mathrm{CO}_{2}, \mathrm{SO}_{2}$. In addition, many studies have shown that the environmental effect of water vapor resulting from hydrogen combustion is negligible in subsonic cruise levels [11]. Chemical properties of hydrogen is shown table 1 . The auto-ignition temperature of hydrogen is $585^{\circ} \mathrm{C}$, which is relatively high. This prevents the hydrogen / air mixture from auto-ignition without additional ignition source [4, 13]. However, the most important difficulty limiting the use of hydrogen is stored at $-253^{\circ} \mathrm{C}$ in liquid form because it occupies a larger volume with the reason that it is very low density $[5,14]$. Liquid form of hydrogen requires well insulated tanks [11]. Advantages and disadvantages of using hydrogen as fuel in aviation are presented in detail in [4-5, 11-14].

The first work on using hydrogen fuel on airplanes (if not consider the balloons) was carried out in 1956 with United States has begun flying a B57 bombed Canberra plane using hydrogen fuel, which is pressurized with helium in one of its engines [14]. This adventure, which started with the separation of hydrogen from water by electricity, has come to the use of fuel cells now. Hydrogen fuel cells have begun to be used for the first time in space shuttles and other high-tech applications when a clean and efficient power supply is needed. Detailed information of the fuel cell application on aviation sector can be found in the second section of this treatise.

This review paper presents the state of art on hydrogen usage on aviation. Brief history, possibilities of using hydrogen as a fuel, storage, production, fuel cell applications and compared with literature.

\section{STATE OF ART USING HYDROGEN}

\subsection{Hydrogen Production}

Although hydrogen is one of the most abundant elements in the universe, it does not exist alone because it easily reacts with other elements. For this reason, hydrogen production is based on the principle of removal of other molecules [15]. Hydrogen can be produced from a diversity of feed stocks. These are fossil resources, like as natural gas and coal, with addition to renewable resources, such as biomass and water [16]. In 2006, the hydrogen production sources can be expresses with amount of; $48 \%$ natural gas, $30 \%$ oil, $18 \%$ coal, $4 \%$ electrolyses and other negligible sources [17]. An overview of multiple hydrogen production methods and various end-users is presented in Figure 1.a [18] and the percentages of hydrogen production methods are shown in Figure 1.b.

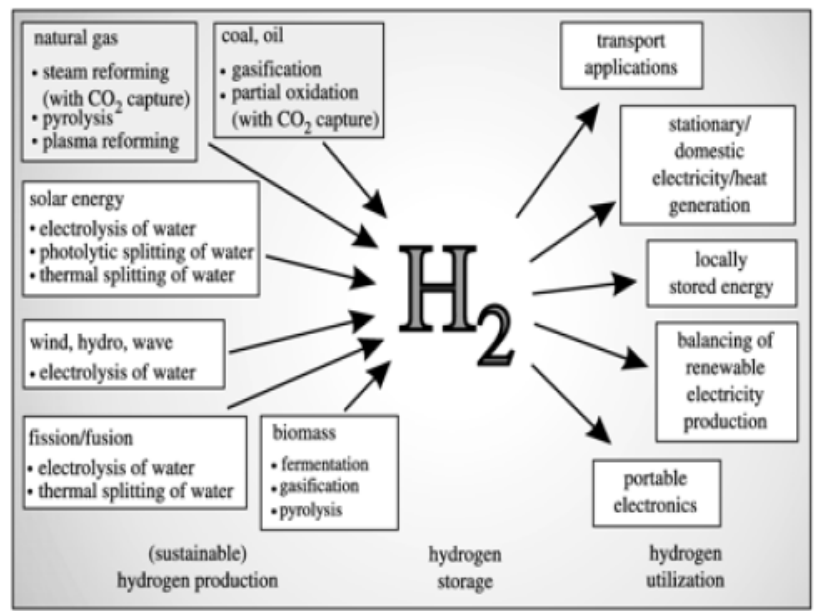

\section{Hydrogen Production Sources}

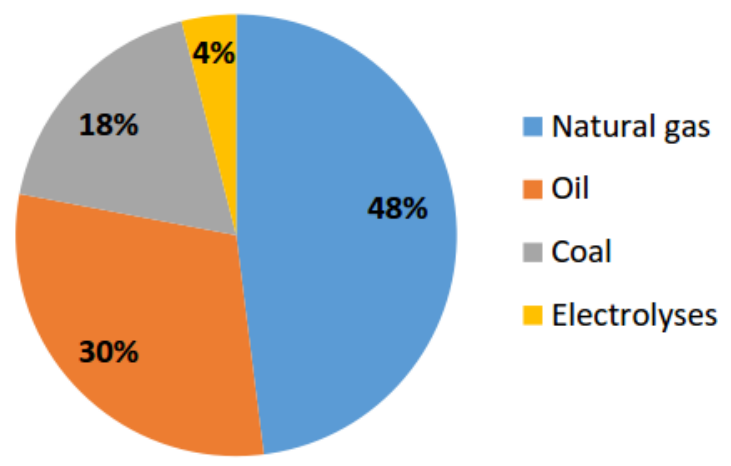

Fig. 1.a Hydrogen production methods and various end-users [18] 1.b percentage of hydrogen production sources.

\section{Hydrogen from fossil fuels}

The cheapest production feedstock to produce hydrogen is fossil fuels, but new methods are being developed as fossil fuel use limited reserves and pollute the environment [15]. Hydrogen can be generated from a lot of fossil fuels, mainly natural gas and coal. It can be produced from natural gas in three different ways: steam reforming, auto-thermal reforming and partial oxidation [16].

In the steam reforming method, methane and water vapour are converted to hydrogen and carbon monoxide by endothermic conversion as in equation 1 [17].

$$
\mathrm{CH}_{4}+\mathrm{H}_{2} \mathrm{O}+\text { heat } \rightarrow \mathrm{CO}+3 \mathrm{H}_{2}
$$

In the reaction occurring between $850^{\circ} \mathrm{C}-700^{\circ} \mathrm{C}$ and 3- 25 bar, the heat usually comes from the combustion of part of the methane feed gas [17]. The product gas containing about $12 \% \mathrm{CO}$ can be further converted to $\mathrm{CO}_{2}$ and $\mathrm{H}_{2}$ by water-gas shift reaction as in equation 2 [16]. 


$$
\mathrm{CO}+\mathrm{H}_{2} \mathrm{O} \rightarrow \mathrm{CO}_{2}+\mathrm{H}_{2}+\text { heat }
$$

In partial oxidation, which is exothermic reaction, partial combustion of methane with oxygen gas forms carbon monoxide and hydrogen as in equation 3 [17].

$$
\mathrm{CH}_{4}+1 / 2 \mathrm{O}_{2} \rightarrow \mathrm{CO}+2 \mathrm{H}_{2}+\text { heat }
$$

Auto-thermal reforming, which is exothermic reaction, is a combination of both steam reforming (Eq.1) and partial oxidation (Eq.3) [19]. In the auto-thermal reforming process, where the outlet temperature from the reactor can between from 950 to $1100^{\circ} \mathrm{C}$ and the gas pressure can be up to $100 \mathrm{bar}$, the produced $\mathrm{CO}$ is transformed into $\mathrm{H} 2$ as in equation 2 [16-17].

Coal can be transformed into hydrogen by means of several of endothermic gasification processes like fixed bed, fluidized bed and entrained flow. Various parameters like the reactor size, the desired gas utilization and quality effect the selection of the appropriated technology. In a classical gasification reaction, the fuel and the gasification agent are converted into a mixture containing mainly carbon monoxide and hydrogen as in equation 4 [19].

$$
\mathrm{C}(\mathrm{s})+\mathrm{H}_{2} \mathrm{O}+\text { heat } \rightarrow \mathrm{CO}+\mathrm{H}_{2}
$$

\section{Hydrogen from renewable energies}

Although hydrogen has a wide variety of sources of production, as fossil fuels have gradually decreased, the use of water in production has become increasingly advantageous [14]. The water electrolysis, shown in equation 5, is the process of separating oxygen and hydrogen from water using direct electric energy by redox reaction [16]. A large amount of electrical energy is required for electrolysis to take place, but the reaction is completely environmentally friendly and renewable [15].

$$
\mathrm{H}_{2} \mathrm{O}+\text { electricity } \rightarrow \mathrm{H}_{2}+1 / 2 \mathrm{O}_{2}
$$

In alkaline electrolysis, an advanced technology, water in the cathode consumes electrons to form hydrogen. Hydroxide ions migrate by means of the solution in the direction of the anode at which they release the electrons. A typical reaction for the process is given in equation 6 [19].

Cathode: $2 \mathrm{H}_{2} \mathrm{O}^{+}+2 \mathrm{e}^{-} \rightarrow \mathrm{H}_{2}+2 \mathrm{OH}^{-}$

Anode: $\quad 2 \mathrm{OH}^{-} \rightarrow 1 / 2 \mathrm{O}_{2}+\mathrm{H}_{2} \mathrm{O}+2 \mathrm{e}^{-}$

Sum: $\quad \mathrm{H}_{2} \mathrm{O} \rightarrow 1 / 2 \mathrm{O}_{2}+\mathrm{H}_{2}$

Using a solid polymer membrane as the electrolyte in the PEM electrolyzer greatly improves the conductivity issues associated with the use of a liquid electrolyte. The main difference between alkaline electrolyzers and PEM electrolyzers is the use of a solid polymer membrane electrolyte instead of the liquid electrolyte [19-20]. The reaction is as shown in equation 7 .

Cathode: $2 \mathrm{H}^{+}+2 \mathrm{e}^{-} \rightarrow \mathrm{H}_{2}$

Anode: $\quad \mathrm{H}_{2} \mathrm{O} \rightarrow 1 / 2 \mathrm{O}_{2}+\mathrm{H}^{+}+2 \mathrm{e}^{-}$

Sum: $\quad \mathrm{H}_{2} \mathrm{O} \rightarrow 1 / 2 \mathrm{O}_{2}+\mathrm{H}_{2}$

Unlike alkaline and polymer membrane electrolysis operating at low temperature $\left(<100^{\circ} \mathrm{C}\right)$, solid oxide electrolysis runs at high temperature $\left(<1000^{\circ} \mathrm{C}\right)$. This situation results in higher efficiency [20]. On the cathode side, water or rather steam is reduced to produce hydrogen to form oxide ions. The reaction is as shown in equation 8 [20].

Cathode: $\mathrm{H}_{2} \mathrm{O}+2 \mathrm{e}^{-} \rightarrow \mathrm{H}_{2}+\mathrm{O}^{2-}$

Anode: $\quad \mathrm{O}^{2-} \rightarrow 1 / 2 \mathrm{O}_{2}+2 \mathrm{e}^{-}$

Sum: $\quad \mathrm{H}_{2} \mathrm{O} \rightarrow 1 / 2 \mathrm{O}_{2}+\mathrm{H}_{2}$

Thermo-chemical water splitting converts water into hydrogen by means of various chemical reactions. In this transformation, high heat sources such as solar and nuclear are used instead of electricity [19]. Stadler [19] elaborated that the thermo-chemical water splitting methods like sulfur - iodine, sulfur hybrid and hybrid copper chloride.

\subsection{Hydrogen Storage}

There are still some challenges that are not solved about of using hydrogen in the entire aviation sector, especially fuel-cell powered UAVs (unmanned air vehicles), although there are many researches and applications related to expire. 
Gong and Verstraete [21] put forward these problems in their study. They mentioned that because of aircraft weight and volume constrained aircraft design areas, it is difficult to efficiently store, produce and use of hydrogen. In addition, the low hydrogen gas density $\left(0.089 \mathrm{~kg} / \mathrm{m}^{3}\right.$ at standard temperature and pressure) requires alternative methods to transport hydrogen in a volumetrically efficient way. In addition that, also Colozzo [22] touched upon these problems. He suggested the hydrogen's high energy density is brilliant and have a good potential fuel for aircrafts. However, in most applications, the use of hydrogen requires large volumes. For this reason, the intensity of hydrogen should be increased to make it useful in aircraft applications.

In this subsection, the methods of hydrogen storage systems are expressed detailed and advantages and disadvantages of these systems are given. Generally hydrogen storage divided into two sections which are physical and chemical storages. In Figure 2, the hydrogen storage diagram is illustrated. The detailed of brief explanations of the matters can be seen below which they are used in aviation sector.

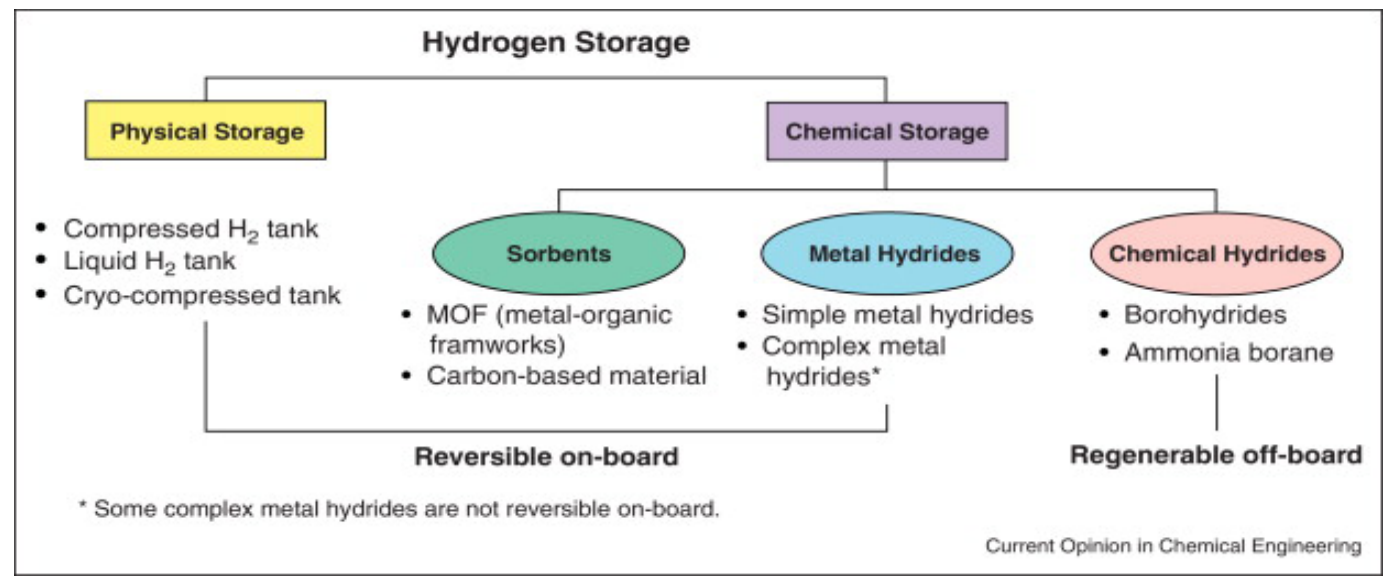

Fig.2 Hydrogen storage diagram [23].

\subsubsection{Physical Storage}

\section{Compressed $\mathrm{H}_{2}$ tank}

According to widespread belief, the most conventional and simplest type of hydrogen storage is compressed hydrogen storage [22]. Because of its low density, hydrogen is stored in compressed form [24]. In compressed gas tanks in where hydrogen gas density increases as pressure increases [22], storage pressures are between $35 \mathrm{Mpa}$ and $70 \mathrm{Mpa}$. [21]. Although very high pressures make fuel filling difficult, the advantages of this method are the rapid filling releasing rate is possible and the easiness of technology [21]. The main disadvantage of this method is that the volumetric density does not increase as the pressure increases [20]. When it comes to recent progresses, a carbon overwrapped aluminum pressure compressed gas tank, in the Ion Tiger program at the NRL (Naval Research Laboratory), stored $500 \mathrm{~g} \mathrm{H}_{2}$ at $34 \mathrm{MPa}$ and the system weight was reduced to $8 \mathrm{Ib}$. [21,25].

\section{Liquid $\mathrm{H}_{2}$ tank}

Very low temperatures are required to store the hydrogen in the cryogenic form [21]. Liquid hydrogen is maintained at a temperature of nearly-260 C and has a density of about $71 \mathrm{~kg} / \mathrm{m}^{3}$ [22]. The properties of liquid hydrogen make possible both significant increase in density over high-pressure gas storage and reduced tank mass due to lower pressure operation. [22].Compared to the gaseous state, since liquid hydrogen has a higher volumetric capacity $(0.07 \mathrm{~kg} / \mathrm{L})$, more hydrogen is stored than compressed gas tanks $(0.039 \mathrm{~kg} / \mathrm{L}$ at $700 \mathrm{bar})$ for a given volume [26]. Şenel [14] mentioned the importance of liquid hydrogen storage in aviation, and told that $\mathrm{LH}_{2}$ (liquefied hydrogen) is preferred because of its experience in spacecrafts. Also, high density ratios of $\mathrm{LH}_{2}$ offer an important advantage when compared to gaseous one. Gong and Verstraete [21] told that according to studies conducted by the NRL, in micro unmanned air vehicle, using liquid hydrogen instead of compressed gas may provide an increase in flight time from 26 to 72 hours and he positive properties of liquid hydrogen are a promising potential for UAVs. However, nowadays liquid hydrogen-driven UAVs are not common because liquid hydrogen is produced outside and transported to the UAV.

Although hydrogen is filled with opportunities for use as a liquid fuel, it presents major drawbacks encountered whit its usage. These drawbacks are listed by [22] as;

"1. It requires an airtight insulation system to reduce the boil-off of the liquid hydrogen and maintain it at cryogenic temperatures.

2. Liquid hydrogen handling requires specialized equipment and procedures. Also the storage of liquid hydrogen is time 
limited (due to boil-off) so the fuel usually needs to be manufactured on site or at a nearby location.

3. The fuel tanks need to be maintained at a constant pressure, usually around 21 psia to minimize boil-off. This requires a venting system and procedure to be implemented.

4. Liquid hydrogen tanks and lines must be sealed off from the atmosphere. If air enters the tanks it will freeze solid and can block the flow lines. Only helium can be used as a purge gas" [22].

Colozza [22] studied hydrogen storage methods and their applicability in detail in aviation applications. He mentioned the ways to increase the hydrogen density, which is the gold rule for using hydrogen in aviation applications. One of the ways of the solution and generation to further increase the density of liquid hydrogen is to produce gelled liquid hydrogen. Gelled hydrogen, producing by introducing a gellant into the liquid hydrogen, can provide up to $10 \%$ increase in liquid hydrogen density as well as reduces the boil-off rate by 2 to 3 times compared to liquid hydrogen.

The boil-off phenomenon is also another important item that will affect efficiency. Owing to the heat transfer on the storage vessel, 2-3\% of evaporated hydrogen will be lost per day [20]. The amount of hydrogen stored, effectiveness of the thermal insulation, ambient conditions, geometry of the vessel, and length of time between driving are the factors which influence the amount and rate of hydrogen boil-off. [26]. Hydrogen vapor is formed by heat leakage into the tank through the insulation. The cryo-cooler is used to intensify the hydrogen vapor in the ullage [22].

Recent research has shown that the design of the cryogenic carbon fiber composite tank can be combined with high pressure capacity, namely the tank can be filled with liquid hydrogen and pressurized to 275 bar or even 350 bar. This new storage system provided the critical DoE 2015 volumetric efficiency goal [20].

\subsubsection{Chemical Storage}

\section{Metal hydrides}

Metal hydrides, which absorb hydrogen, are metallic alloys. These alloys can be used as a storage mechanism with their ability for both absorb and release hydrogen [22]. Hydrides temperature effects directly to release of hydrogen. As already known metal hydrides can hold hydrogen equal to approximately $1 \%$ to $2 \%$ of their weight. Only if active heating is provided to remove the hydrogen, this can increase to $5 \%$ to $7 \%$ of the hydride weight. [22]. However, in terms of aviation, even such a technological development still remains a major disadvantage, since the weight of the metal hybrid to be described as a fuel tank will need to be greater than 100 tons [14].

\section{Carbon nanotubes}

Carbon nanotubes have attracted interest as hydrogen storage materials that they had their high surface areas and thermal stability [23]. Carbon nanotubes are tubular carbon structures in the style of 2 nanometers in size and theoretically these structures can store hydrogen in the tube structure [22]. Carbon nanotubes and metal hybrids resemble each other with storage methods. However, the amount of hydrogen stored in nanotubes can be much higher, so the developing nanotube technology is seen as a promising method in hydrogen storage, especially in aviation sector [14].

\section{Glass microspheres}

In this developing method, hollow glass spheres smaller in size than a salt grain can be used for hydrogen storage [14]. The basic concept and working procedure is summarized by [16] as, the hydrogen storage method with glass microspheres can be explained by three steps: charging, filling and discharging. First, at high pressure (350-700 bar) and high temperature (ca. $\left.300{ }^{\circ} \mathrm{C}\right) \mathrm{H}_{2}$ is filled into hollow glass spheres by permeation in a high-pressure vessel. Then, cooled microspheres (down to room temperature) transferred to the low-pressure vehicle tank. Lastly, the microspheres are heated to ca. $200-300{ }^{\circ} \mathrm{C}$ for the purpose of controlled release of H2. [16].

Filling and purge rates are directly proportional to the hydrogen permeability of the glass spheres. Hydrogen permeability increases with increasing temperature. For instance, the filling / purge rate at room temperature is 5000 hours, while it is about 15 minutes at $300{ }^{\circ} \mathrm{C}[22]$.

\section{Chemical hydrides}

Chemical hydrides with higher energy density because they contain lighter elements attract more attention than metal hydrides. Furthermore, it is possible to use them for storing the hydrogen under relatively mild operating conditions [23].

Sodium borohydride $\left(\mathrm{NaBH}_{4}\right)$ is the most investigated chemical storage compound for UAVs. Advantages of sodium borohydride include: stable reaction, rapid reaction at ambient temperature, low hydrolysis heat, and a more stable and easy to handle fuel source compared to liquid or compressed hydrogen [21]. Equation 9 notes that the sodium borohydride 
can provide relatively high theoretical hydrogen efficiency (10.8 wt \%) with hydrolysis reaction [23] :

$$
\mathrm{NaBH}_{4}+2 \mathrm{H}_{2} \mathrm{O} \rightarrow \mathrm{NaBO}_{2}+4 \mathrm{H}_{2}
$$

KAIST (Korea Advanced Institute of Science and Technology) demonstrated the use of sodium borohydride to achieve a 5 hour flight time, in 2007. This study performed with a blended wing body micro air vehicle (MAV) that was combined with a $50 \mathrm{~W}$ fuel cell (two $25 \mathrm{~W}$ fuel cells), which powered the aircraft during cruise. Battery power was ensured the take-off stage. This fuel cell system with NaBH4 tank proved an energy density of $1000 \mathrm{Wh} / \mathrm{kg}$ [21].

Ammonia borane with high material capacity $\left(19.6 \mathrm{wt} \% \mathrm{H}_{2}\right)$ is a promising candidate among chemical store material and hydrogen is released by hydrolysis or thermolysis. [21, 23]. The dehydrogenation of the ammonia borane with the delivery of hydrogen (in $120-180^{\circ} \mathrm{C}$ ) is clarified by the following equation 10 [21].

$$
\mathrm{NH}_{3} \mathrm{BH}_{3} \rightarrow \mathrm{NH}_{2} \mathrm{BH}_{2}+\mathrm{H}_{2}
$$

In 2013, KAIST and the Korean research institute have developed the UAV, which has $2.9 \mathrm{~m}$ wingspan and $7.5 \mathrm{~kg}$ take-off weight. This UAV using an ammonia-borane hydrogen generator provided a flight time of 57 minutes [21].

\subsection{Fuel Cells}

Green aviation is developing by increasing importance. Balancing the power and emission scale, all transport industry going to planning electrification propulsion [27]. There are several advantages of electric power that can count like efficiency, reliability, low cost, low thermal and noise signature, low vibration, ...etc [21]. The electric power can be supplied by state-of-the-art technology batteries or fuel-cell-based systems that provide higher specific energy compared with batteries [21].

The main goal of usage FCs are; generated the electricity with electrochemical reactions from water via decompose oxygen and hydrogen. The development of FC is based on historical background by the 1839s. After Sir William Grove's invention in those times, FCs are attracted the interest of researchers as a new and reliable energy provider. For detailed historical review of 100 years of FCs; please check the reference [41].

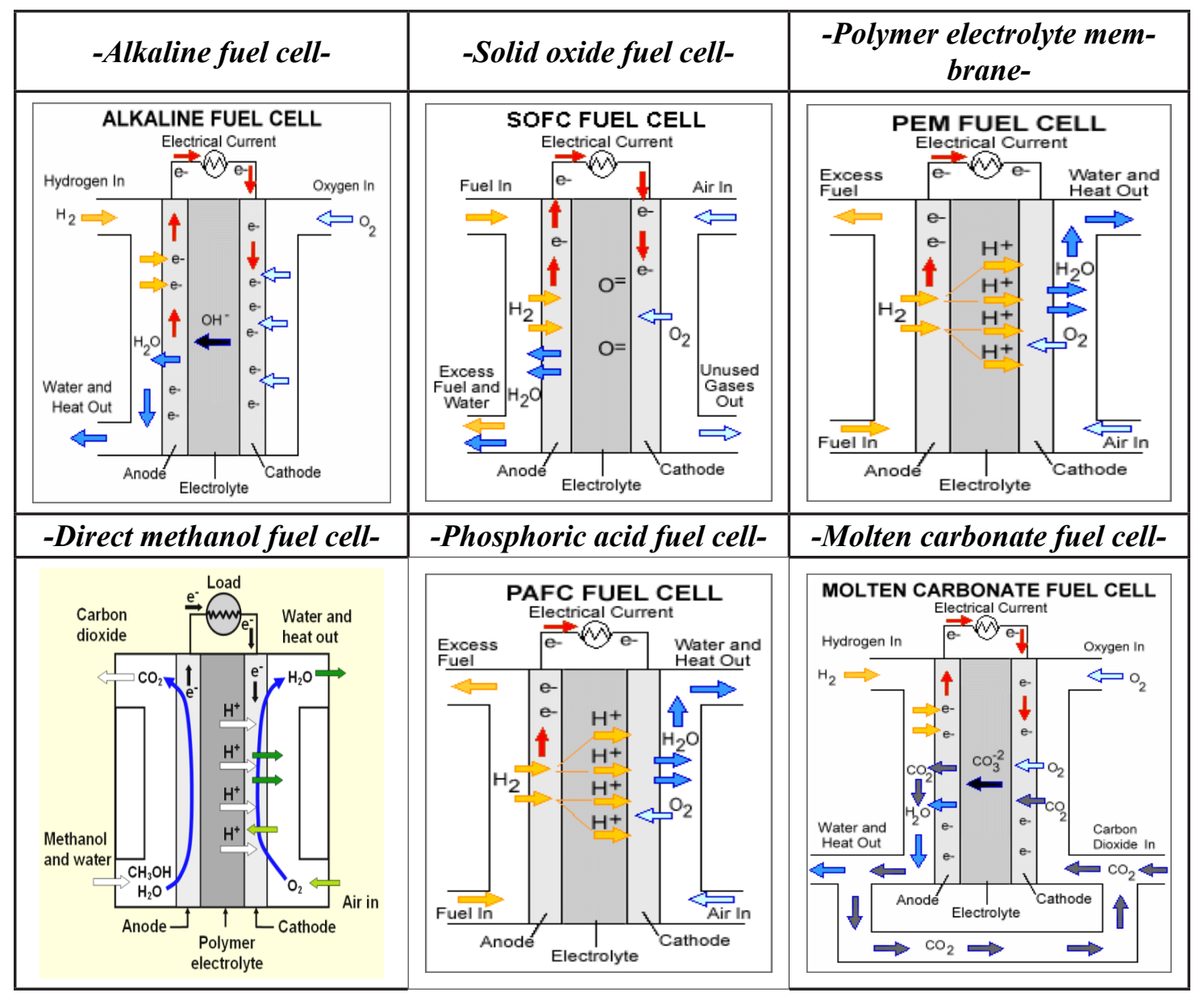

Fig.3 The working principles of various fuel cells [Re-drawing from 33]

Greener fuel cells are electrochemical devices that convert the chemical energy of fuel into electric energy [28]. Fuel 
cells and batteries are quite alike because of consist electrochemical cells that have two electrodes wraps an electrolyte and both use internal oxidation-reduction reactions in the process to convert chemical energy into electric energy [29]. However, on one side battery holds a closed store of energy within it and obligated for charge/discharge situation with an external supply of electricity to occur the electrochemical reaction for the contrary. A fuel cell, on the other hand, uses an external supply of chemical energy and can drive indefinitely with a source of hydrogen and a source of oxygen [30]. Additionally, improved rechargeable batteries can attain energy densities of $150 \mathrm{Wh} / \mathrm{kg}$ at the module level whereas regenerative fuel cells can achieve $>800 \mathrm{Wh} / \mathrm{kg}$ at the system level and non-regenerative fuel cells can achieve $>1000 \mathrm{Wh} /$ $\mathrm{kg}$ [31]. Ion transfer, in a fuel cell, differs in varied cell types [32]. The working principles of various fuel cells are illustrated in figure 3 .

Although fuel cells are a clean and effective mechanism for energy conversion, they have many disadvantages. Some of them can be listed as; late response to transient loads, requiring a larger volume for a given power, and having a lower specific power (W/ kg) compared to combustion engines $[21,29]$ Some of most used and applicant FCs were given with mini definitions below. Properties of mostly used fuel cells in aviation are given table 2 .

\section{Polymer electrolyte membrane fuel cells}

PEMFCs are the most promising candidates for transport applications [29].Some features of the PEMFC, such as working at low temperatures, partly higher power density, quick response to load changes, make it suitable for flight demands [21]. The PEM, whose efficiency ranges from 40 to 60\%, achieves the highest yield at partial loads [21]. HY4, the world's first hydrogen fuel-cell powered four seat passenger aircraft, is running with this type of FC energy for an example of mild aviation [34].

\section{Direct methanol fuel cells}

Direct methanol fuel cells (DMFCs) are similar conceptions with PEMFCs and operate at low temperatures, which give opportunity fast start-up and rapid load following. However, the fuel is transferred via hydrogen to methanol which can be seen below in equation 11 [21].

$$
\mathrm{CH}_{3} \mathrm{OH}+\mathrm{H}_{2} \mathrm{O} \rightarrow \mathrm{CO}_{2}+6 \mathrm{H}^{+}+6 \mathrm{e}^{-} \quad, \quad 1.5 \mathrm{O}_{2}+6 \mathrm{H}^{+}+6 \mathrm{e}^{-} \rightarrow 3 \mathrm{H}_{2} \mathrm{O}
$$

DMFC, having an efficiency of 20-30\%, requires the transport of a larger mass of methanol to produce the same amount of energy compared to PEMFC [21]. Additionally, DMFC usage in aviation sector is expressed by [37], as an example by means of application; lightweight $200 \mathrm{~W}$ stack for unmanned small UAV. DMFC consists of 33 cells and produced $251 \mathrm{~W}$ at $13.4 \mathrm{~V}$ and $74^{\circ} \mathrm{C}$. They concluded that, DMFC stack given maximum power for cruise flight but battery needs additional power for takeoff. A comparative design method for FC usage in UAVs is performed by [38]. They give brilliant information and approaches for DMFC and SOFC with detailed table.

\section{Solid oxide fuel cells}

Solid oxide fuel cells (SOFCs) principal structure is given in figure 3. Advantage of SOFCs is come with the high temperature. SOFCs can use hydrocarbon fuels such as propane, which improves fuel-availability and reduces storage demands. However these high temperatures must be carefully managed and SOFCs take time to warm up and reach operating temperature, so they cannot respond to (rapid) changes in load [28]. SOFC is the one of the most important component in FC family for usage in aviation applications. Especially for UAV, SOFC and PEMFC are most preferable FCs. A study which conducted by [39] reported the results of using (SOFC) in a hybrid APU system for a commercial aircraft. They expected the important advices about the hybrid SOFC/GT and their study conditions. Additionally, [40] given a SOFC system architecture and comparative analyses in their study.

Table 2 The properties of mostly used fuel cell on aviation [data gathered from 20, 21, 29].

\begin{tabular}{|c|c|c|c|l|}
\hline Fuel cell type & Fuel & Operating temperature $\left({ }^{\circ} \mathrm{C}\right)$ & Efficiency $(\%)$ & \multicolumn{1}{|c|}{ Reactions } \\
\hline PEMFC & Hydrogen & $30-100$ & $40-60$ & $\begin{array}{l}\text { Anode: } \mathrm{H}_{2} \rightarrow 2 \mathrm{H}^{+}+2 \mathrm{e}^{-} \\
\text {Cathode: } 1 / 2 \mathrm{O}_{2}+2 \mathrm{H}^{+}+2 \mathrm{e}^{-} \rightarrow \mathrm{H}_{2} \mathrm{O}\end{array}$ \\
\hline DMFC & Methanol & $20-90$ & $20-30$ & $\begin{array}{l}\text { Anode: } \mathrm{CH}_{3} \mathrm{OH}+\mathrm{H}_{2} \mathrm{O} \rightarrow \mathrm{CO}_{2}+6 \mathrm{H}^{+}+6 \mathrm{e}^{-} \\
\text {Cathode: } 3 / 2 \mathrm{O}_{2}+6 \mathrm{H}^{+}+6 \mathrm{e}^{-} \rightarrow 3 \mathrm{H}_{2} \mathrm{O}\end{array}$ \\
\hline SOFC & Hydrocarbon & $500-1000$ & $30-50$ & $\begin{array}{l}\text { Anode: } \mathrm{H}_{2}+\mathrm{O}^{2-} \rightarrow \mathrm{H}_{2} \mathrm{O}_{+} 2 \mathrm{e}^{-} \\
\text {Cathode: } 1 / 2 \mathrm{O}_{2}+2 \mathrm{e}^{-} \rightarrow \mathrm{O}^{2-}\end{array}$ \\
\hline AFC & Hydrogen & $150-200$ & $60-70$ & $\begin{array}{l}\text { Anode: } \mathrm{H}_{2}+2 \mathrm{OH}^{-} \rightarrow \mathrm{H}_{2} \mathrm{O}_{+}+2 \mathrm{e}^{-} \\
\text {Cathode: } \frac{1}{2} \mathrm{O}_{2}+\mathrm{H}_{2} 0+2 \mathrm{e}^{-} \rightarrow 2 \mathrm{OH}^{-}\end{array}$ \\
\hline
\end{tabular}

\section{Alkaline fuel cells}

The Alkaline Fuel Cell (AFC) which was one of the first modern fuel cells that were developed in 1960. While the application at that time was proving on-board electric power for the Apollo space vehicle, the AFC continues to be used now 
with provides on-board power for the Space Shuttle Orbiter with cells manufactured by UTC Fuel Cells [28].

\section{DEVELOPMENT OF HYDROGEN USAGE APPLICATIONS IN AVIATION}

The study of the usage of hydrogen as fuel in airplanes started in 1956. The United States achieved flying a B57 Canberra plane which using pressurized hydrogen fuel with the helped of helium in one of its engines that the system of plane [14]. After B57, the Soviets tested experimental conversion of an early production Tu-154 which has one engine operating on hydrogen in 1988. As test result, the liquid hydrogen powered motor was tested at heights up to $7000 \mathrm{~m}$ and accelerated to $900 \mathrm{~km} / \mathrm{h}$. Unfortunately the liquid hydrogen (LH) program was reduced to only five flights and was decided not to continue with such fuels because of high costs and lack of infrastructure of hydrogen [35].

Until today, many hydrogen prototype aircraft such as tupolev Tu-155 (Tupolev, 2009), the Antares DLR-H2 (Fuel Cell Works, 2009), the Boeing phantom eye (Jackson and Haddox, 2010) and the ENFICA-FC Rapid 200-FC (European Commission, 2011) were built using compression and liquefaction storage methods[4]. The historical development timescale for liquid hydrogen and fuel cell powered aircrafts is illustrated in figure 4.

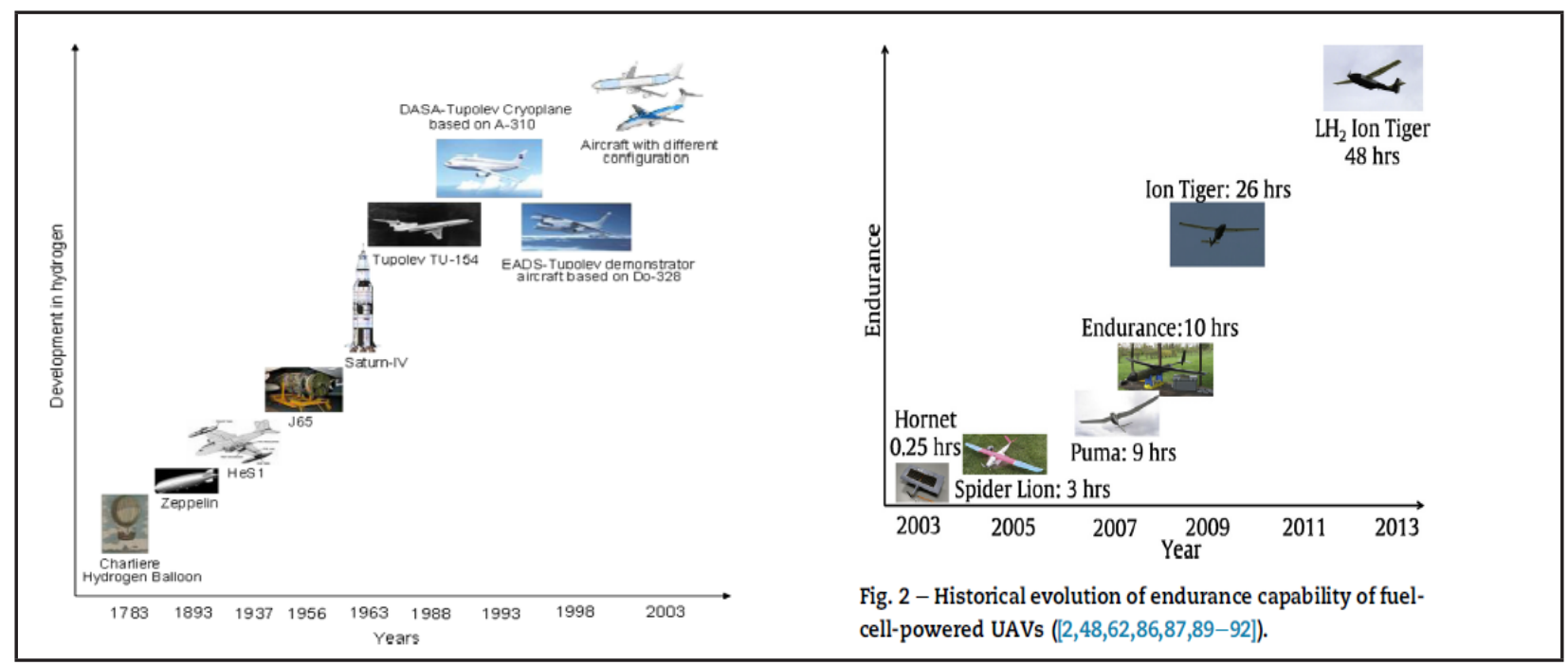

Fig. 4 Historical development timescale for hydrogen (left) and fuel cell (right) powered aircrafts [36, 21].

In the near future, In September 2016, the world's first hydrogen fuel cell-powered four-seat passenger aircraft, HY4, is created its first flight in Stuttgart Airport. In this future electric taxi; the hydrogen fuel is stored at a pressure between 4,300 PSI and 5,800 PSI in two carbon-fiber tanks which both located in the two fuselages. In this aircraft with a maximum speed of $200 \mathrm{~km} / \mathrm{h}$, the fuel cell converts directly converts the hydrogen to electricity and the only waste product that comes out of this process is water. [34].

\section{CONCLUSION}

Green aviation will play an important role in future aviation strategies and applications. More greening can be achieved with the minimized the emission (insomuch as emission-less) of air vehicles. For that purpose hydrogen has an opportunity of using in aviation applications as a fuel. In this mini review, the state of art the usage of hydrogen in aviation is expressed briefly with the light of hydrogen production, storage, fuel cells and applications for drones to space shuttles. The key to launching and disseminating hydrogen on airplanes is to move towards storage and production problems and make progress on this area. There are many ways to store hydrogen in airplanes. However, the desired and full efficiency cannot be obtained from any method including cryogenic storage. A lot of liquid hydrogen is considered necessary for a plane to fly. In the hydrogen production, the use of fossil fuels with limited reserves does not fit the purpose of hydrogen efficacy. It is foreseen that the most comfortable and economical way for the world to choose hydrogen as aircraft fuel in the future is to produce hydrogen with nuclear energy. Although hydrogen engineering challenges can be solved by developing technology, high costs still make it difficult for researchers to work on this issue. In the near future, new technologies in storage and production will be developed and if costs reduced; Hydrogen which is the one of the cleanest fuels, will spread its use in air vehicles.

\section{REFERENCES}

[1] Singh, V., \& Sharma, S. K. (2015). Fuel consumption optimization in air transport: a review, classification, critique, simple meta-analysis, and future research implications. European Transport Research Review, vol. 7, no. 2, p.12, DOI 10.1007/ s12544-015-0160-x 
[2] Boeing :Summary outlook 2008-2027, http://81.47.175.201/transvisions/documents/air/boeing_cmo_summary_2008.pdf [Accessed in December 2017]

[3] Boeing frontiers, September 2008, Volume VII, Issue V, http://www.boeing.com/news/frontiers/archive/2008/september/ sep08frontiers.pdf [Accessed in December 2017]

[4] Dincer, I., \& Acar, C. (2016). A review on potential use of hydrogen in aviation applications. International Journal of Sustainable Aviation, vol. 2, no. 1, p. 74-100, DOI: 10.1504/IJSA.2016.076077.

[5] Bicer, Y., \& Dincer, I. (2017). Life cycle evaluation of hydrogen and other potential fuels for aircrafts. International Journal of Hydrogen Energy, vol. 42, no. 16, p. 10722-10738, DOI: 10.1016/j.ijhydene.2016.12.119

[6] Curl, H. C., \& O’Donnell, K. (1977). Chemical and physical properties of refined petroleum products (No. ERL MESA-17). US Department of Commerce, National Oceanic and Atmospheric Administration, Environmental Research Laboratories.

[7] Facts and Figures, Air Transport Action Group, May 2016, http://www.atag.org/facts-and-figures.html_[Accessed in August 2017].

[8] Koroneos, C., Dompros, A., Roumbas, G., \& Moussiopoulos, N. (2005). Life cycle assessment of kerosene used in aviation (8 pp). The International Journal of Life Cycle Assessment, vol. 10, no. 6 , p. 417-424, DOI: 10.1065/lca2004.12.191.

[9] Sharpe, J. E., Bimbo, N., Ting, V. P., Rechain, B., Joubert, E., \& Mays, T. J. (2015). Modelling the potential of adsorbed hydrogen for use in aviation. Microporous and Mesoporous Materials, vol. 209, p. 135-140, DOI: 10.1016/j.micromeso.2014.08.038.

[10] Verstraete, D. (2013). Long range transport aircraft using hydrogen fuel. International Journal of Hydrogen Energy, vol. 38, no. 34, p. 14824-14831, DOI: 10.1016/j.ijhydene.2013.09.021.

[11] Koroneos, C. J., \& Moussiopoulos, N. (2002). Cryoplane -hydrogen vs. kerosene as aircraft fuel. Proceedings of the Geophysical Society XXVII General Assembly, Nice, France, p. 21-26.

[12] Contreras, A., Yiğit,., Özay, K., \& Veziroğlu, T. N. (1997). Hydrogen as aviation fuel: a comparison with hydrocarbon fuels. International Journal of Hydrogen Energy, vol. 22, no. 10-11 , p. 1053-1060, DOI: 10.1016/S0360-3199(97)00008-6.

[13] Hydrogen Fuel Cell Engines and Related Technologies. Module 1: Hydrogen Properties. U.S. DOE. 2001, https://www1.eere. energy.gov/hydrogenandfuelcells/tech_validation/pdfs/fcm01r0.pdf [Accessed in December 2017].

[14] Şenel, K. (2007), Hidrojenin yakıt olarak uçaklarda kullanımı. yüksek lisans tezi, Eskişehir Osmangazi Üniversitesi, Fen Bilimleri Enstitüsü.

[15] Hydrogen Fuel Cell Engines and Related Technologies. Module 2: Hydrogen Use. U.S. DOE. 2001, https://energy.gov/sites/ $\mathrm{prod} /$ files/2014/03/f10/fcm02r0.pdf [Accessed in December 2017].

[16] Riis, T., Hagen, E. F., Vie P. J. S., Ulleberg, Ø., Sandrock, G.(2006). Hydrogen production and storage, International Energy Agency.

[17] Bhandari,R .,Clemens, A., Trudewind, Zapp,P.(2013).Life cycle assessment of hydrogen production methods - a review, STE research report.

[18] Edwards, P. P., Kuznetsov, V. L., \& David, W. I. F. (2007). Hydrogen energy. Philosophical Transactions of the Royal Society of London A: Mathematical, Physical and Engineering Sciences, vo. 365, no. 1853, p. 1043-1056, DOI: 10.1098/rsta.2006.1965.

[19] Stadler, P. (2014). Cost evaluation of large scale hydrogen production for the aviation industry. Master Semester Project.

[20] Zhang, F., Zhao, P., Niu, M., \& Maddy, J. (2016). The survey of key technologies in hydrogen energy storage. International Journal of Hydrogen Energy, vol. 41, no. 33, p. 14535-14552, DOI: 10.1016/j.ijhydene.2016.05.293.

[21] Gong A., Verstraete D., (2017). Fuel cell propulsion in small fixed-wing unmanned aerial vehicles: Current status and research needs. Int. J. of Hydrogen Energy, vol.42, no. 33, p. 21311-21333, DOI: 10.1016/j.ijhydene.2017.06.148.

[22] Colozza, A. J., \& Kohout, L. (2002). Hydrogen storage for aircraft applications overview. National Aeronautics and Space Administration, Glenn Research Center.

[23] Hwang, H. T., \& Varma, A. (2014). Hydrogen storage for fuel cell vehicles. Current Opinion in Chemical Engineering, vol. 5, p. 42-48, DOI : $10.1016 /$ j.coche.2014.04.004.

[24] Report on hydrogen storage and applications other than transportation.( 2016). Sub-Committee on Hydrogen Storage and Applications Other than Transportation of the Steering Committee on Hydrogen Energy and Fuel Cells Ministry of New and Renewable Energy, Government of India, New Delhi

[25] Swider-Lyons, K. E., MacKrell, J. A., Rodgers, J. A., Page, G. S., Schuette, M., \& Stroman, R. O. (2011, September). Hydrogen fuel cell propulsion for long endurance small UAVs. In The AIAA centennial of naval aviation forum (Vol. 100).

[26] Satyapal, S., Petrovic, J., Read, C., Thomas, G., \& Ordaz, G. (2007). The US Department of Energy's National Hydrogen Storage Project: Progress towards meeting hydrogen-powered vehicle requirements. Catalysis today, vol. 120 , no. 3, p. 246-256, DOI: 10.1016/j.cattod.2006.09.022.

[27] Elitzur, S., Rosenband, V., \& Gany, A. (2017). On-board hydrogen production for auxiliary power in passenger aircraft. International Journal of Hydrogen Energy, vol. 42, no.19 , p. 14003-14009, DOI :10.1016/j.ijhydene.2017.02.037. 
[28] Handbook, F. C. (2004). EG\&G technical services. Inc., Albuquerque, NM, DOE/NETL-2004/1206.

[29] Sharaf, O. Z., \& Orhan, M. F. (2014). An overview of fuel cell technology: Fundamentals and applications. Renewable and Sustainable Energy Reviews, vol. 32, p. 810-853, DOI: 10.1016/j.rser.2014.01.012

[30] http://www.fuelcelltoday.com/technologies. [Accessed in August 2017].

[31] Bradley, T. H., Moffitt, B. A., Thomas, R. W., Mavris, D. N., \& Parekh, D. E. (2006). Test results for a fuel cell-powered demonstration aircraft (No. 2006-01-3092). SAE Technical Paper.DOI:10.4271/2006-01-3092.

[32] Brandon, N., \& Hart, D. (1999). An introduction to fuel cell technology and economics. Centre for Energy Policy and Technology, Imperial College.

[33] http://earthsci.org/mineral/energy/fuelcell/fuelcell.html [Accessed in August 2017].

[34] http://www.aerospace-technology.com/projects/hy4-aircraft/ [Accessed in August 2017].

[35] http://ram-home.com/ram-old/tu-155.html [Accessed in August 2017]

[36] Khandelwal, B., Karakurt, A., Sekaran, P. R., Sethi, V., \& Singh, R. (2013). Hydrogen powered aircraft: the future of air transport. Progress in Aerospace Sciences, vol.60, p. 45-59,DOI: 10.1016/j.paerosci.2012.12.002.

[37] Kang, K., Park, S., Cho, S. O., Choi, K., \& Ju, H. (2014). Development of Lightweight 200-W Direct Methanol Fuel Cell System for Unmanned Aerial Vehicle Applications and Flight Demonstration. Fuel Cells, vol.14, no. 5, p. 694-700.

[38] Bradley, T. H., Moffitt, B. A., Fuller, T. F., Mavris, D. N., \& Parekh, D. E. (2009). Comparison of design methods for fuel-cell-powered unmanned aerial vehicles. Journal of Aircraft, vol. 46, no. 6, p. 1945.

[39] Rajashekara, K., Grieve, J., \& Daggett, D. (2006, October). Solid oxide fuel cell/gas turbine hybrid APU system for aerospace applications. In Industry Applications Conference, 2006. 41st IAS Annual Meeting. Conference Record of the 2006 IEEE, vol. 5, p. 2185-2192. IEEE.

[40] Wu, S., \& Li, Y. (2014, October). Fuel cell applications on more electrical aircraft. In Electrical Machines and Systems (ICEMS), 2014 17th International Conference on, p. 198-201. IEEE.

[41] Perry, M. L., \& Fuller, T. F. (2002). A historical perspective of fuel cell technology in the 20th century. Journal of the electrochemical society, vol. 149, no. 7, p. S59-S67. 